\title{
A systematic review and meta-analysis of risks and benefits with breast reduction in the public healthcare system: priorities for further research
}

\author{
Emmelie Widmark-Jensen 1,2, Susanne Bernhardsson 3,4,5 @ , Maud Eriksson ${ }^{4,7}$, Håkan Hallberg ${ }^{2}$, \\ Christian Jepsen 1,2, Lennart Jivegård ${ }^{4}$, Ann Liljegren ${ }^{4,7}$, Max Petzold ${ }^{4,8}$, Mikael Svensson ${ }^{4,9}$ (D, \\ Fredrik Wärnberg ${ }^{1,6}$ (1) and Emma Hansson ${ }^{1,2^{*}}$ (i)
}

\begin{abstract}
Background: There is no consensus for when publicly funded breast reduction is indicated and recommendations in guidelines vary greatly, indicating a lack of evidence and unequal access. The primary aim of this review was to examine risks and benefits of breast reduction to treat breast hypertrophy. Secondary aims were to examine how the studies defined breast hypertrophy and indications for a breast reduction.

Methods: A systematic literature search was conducted in PubMed, MEDLINE All, Embase, the Cochrane Library, and Psyclnfo. The included articles were critically appraised, and certainty of evidence was assessed using the GRADE approach. Meta-analyses were performed when possible.

Results: Fifteen articles were included; eight reporting findings from four randomised controlled trials, three nonrandomised controlled studies, three case series, and one qualitative study. Most studies had serious study limitations and problems with directness. Few of the studies defined breast hypertrophy. The studies showed significantly improved health-related quality of life and sexuality-related outcomes in patients who had undergone breast reduction compared with controls, as well as reduced depressive symptoms, levels of anxiety and pain. Most effect sizes exceeded the reported minimal important difference for the scale. Certainty of evidence for the outcomes above is low $(G R A D E \oplus \oplus)$. Although four studies reported significantly improved physical function, the effect is uncertain (very low certainty of evidence, GRADE $\oplus$ ). None of the included studies reported data regarding work ability or sick leave. Three case series reported a 30-day mortality of zero. Reported major complications after breast reduction ranged from 2.4 to $14 \%$ and minor complications from 2.4 to $69 \%$.
\end{abstract}

Conclusion: There is a lack of high-quality studies evaluating the results of breast reduction. A breast reduction may have positive psychological and physical effects for women, but it is unclear which women benefit the most and which women should be offered a breast reduction in the public healthcare system. Several priorities for further research have been identified.

\footnotetext{
*Correspondence: emma.hansson.2@gu.se

1 Department of Clinical Sciences, Sahlgrenska Academy, University

of Gothenburg, Gröna Stråket 8, SE-413 45 Gothenburg, Sweden

Full list of author information is available at the end of the article
} original author(s) and the source, provide a link to the Creative Commons licence, and indicate if changes were made. The images or other third party material in this article are included in the article's Creative Commons licence, unless indicated otherwise in a credit line to the material. If material is not included in the article's Creative Commons licence and your intended use is not permitted by statutory regulation or exceeds the permitted use, you will need to obtain permission directly from the copyright holder. To view a copy of this licence, visit http://creativecommons.org/licenses/by/4.0/. The Creative Commons Public Domain Dedication waiver (http://creativeco mmons.org/publicdomain/zero/1.0/) applies to the data made available in this article, unless otherwise stated in a credit line to the data. 
Pre-registration: The study is based on a Health Technology Assessment report, pre-registered and then published on the website of The Regional HTA Centre of Region Västra Götaland, Sweden.

Keywords: Breast reduction, Reduction mammaplasty, Breast hypertrophy, Plastic surgery, Evidence-based medicine, Prioritizing

\section{Background}

Publicly funded welfare-type healthcare systems with a strong emphasis on equal access to healthcare are increasingly struggling with resource constraints. This requires a standardisation, with continuing re-evaluation, of what should be reimbursed and what should be rationed [1-3]. The nature of plastic surgery entails an element of subjectivity and studies have revealed that there is a variation in what is offered which could indicate a lack of evidence and unequal access [1, 4-7]. One procedure that has been debated, and where guidelines vary, is breast reduction due to breast hypertrophy [3, 5, 8-10].

Breast hypertrophy is a condition that may give rise to both physical and psychosocial symptoms, including muscle pain, such as back and shoulder pain, headache, postural changes, bra strap grooves, intertrigo, inability to participate in exercise and sports, sexual problems, bullying, body image problems, and problems with poorly fitting clothes [11]. Most of the symptoms described impair health-related quality of life (HRQoL). A breast reduction (reduction mammaplasty) is considered effective at reducing physical and psychosocial symptoms and improving HRQoL [12, 13]; however, similar effects are also achieved when a breast reduction is performed for cosmetic reasons and therefore it is difficult to distinguish which patients should be operated in the publicly funded healthcare system $[14,15]$. Moreover, there is no standardisation regarding the assessment and prioritising of functional problems, such as back pain, compared to non-functional problems, for example suffering due to appearance [16].

There is no commonly accepted definition of breast hypertrophy and no consensus for when a breast reduction is indicated and should be reimbursed. Some guidelines define breast hypertrophy according to breast volume. For example, the current national Swedish guidelines [17] base the definition on anthropomorphic measurements of mean breast volume $(405 \mathrm{ml}$, median $359 \mathrm{ml}$ ) in a population of randomly chosen women [18]. Hypertrophy is defined as at least twice the mean volume observed in the anthropomorphic measurement studies; that is, a volume of $>800 \mathrm{ml}$ per breast. Previous Swedish studies, conducted before the guidelines were established, showed that many women who want a breast reduction have a volume of $>800 \mathrm{ml}[19,20]$. Other definitions of breast hypertrophy include the Sacchini criteria
[21] and bra size. The Sacchini criteria [21] are based on the mean measurement of the nipple to the inframammary fold distance and the nipple to the lateral border of the sternum distance. A mean distance of less than $9 \mathrm{~cm}$ is considered to indicate a small breast, $9-11 \mathrm{~cm}$ a normally sized breast and $>11 \mathrm{~cm}$ breast hypertrophy. When bra size is used, a cup D or larger is typically considered to indicate breast hypertrophy. In healthcare systems with third party payers, such as the United States system, insurance companies often assess the medical necessity for a breast reduction based on the amount of tissue that can be removed in a normal weight patient [9], usually according to the The Schnur Sliding Scale [10,22].

The aim of this review was to examine the risks and benefits of breast reduction to treat breast hypertrophy. Specifically, the primary aims were to investigate whether breast reduction is better than no surgery, in women with symptomatic breast hypertrophy and a BMI of $\leq 35$, regarding HRQoL, depressive symptoms, anxiety symptoms, sexuality-related outcomes, work ability, sick leave, physical function, pain, and patient experience, and whether it is safe. Secondary aims were to examine how the studies defined breast hypertrophy and which indications for a breast reduction were used.

\section{Methods \\ Protocol}

This is a systematic review and meta-analyses based on a Health Technology Assessment report [23]. The protocol was pre-registered on the webpage of The Regional Health Technology Assessment Centre of Region Västra Götaland, Sweden (HTA-centrum).

\section{Eligibility criteria and study selection}

Studies examining risks and benefits with breast reduction in breast hypertrophy were included. Included articles had to meet criteria defined in a PICO (population, intervention, comparison, and outcome) [24] (Table 1). A patient was included in the work group when the PICO was defined.

Eligible study designs were randomised controlled trials (RCTs), non-randomised controlled studies comprising $\geq 100$ patients, case series if $\geq 1000$ patients were reported (only for complications), all case reports/series reporting deaths, and qualitative studies. All the authors independently assessed whether the articles met the 
Table $1 \mathrm{PICO}$

\begin{tabular}{ll}
\hline PICO & \\
\hline$P \quad$ & Women who seek health care for symptomatic breast hypertro- \\
phy and with a BMI $\leq 35$ \\
Excluded: Women operated for breast cancer or who have had a \\
breast augmentation \\
Breast reduction \\
C1: no treatment \\
C2: non-surgical treatment \\
Critical for decision-making \\
Mortality \\
Complications \\
Health related Quality of Life (HRQLL) \\
Important for decision-making \\
Depressive symptoms \\
Anxiety symptoms \\
Sexuality-related outcomes \\
Work ability \\
Sick leave \\
Physical function \\
Pain \\
Experiences of having a breast reduction \\
Patient-reported outcomes had to be measured with validated scales
\end{tabular}

inclusion criteria and disagreements were resolved by discussion.

\section{Information sources and search}

In June 2020 two medical librarians (authors AL, $\mathrm{ME}$ ) together performed a search in MEDLINE All (Ovid), PubMed, Embase (Ovid), the Cochrane Library (Wiley) and APA PsycInfo (Ebsco), using controlled vocabulary (MeSH, Emtree) such as breast hyperplasia and breast reduction and relevant free-text terms. The searches for all databases were validated by discussion and are available in Additional file 1. Reference lists of relevant articles were scrutinised for additional references. The web sites of the Swedish Agency for Health Technology Assessment and Assessment of Social Services (SBU) and the Norwegian Institute of Public Health were visited. The search was limited to English, Swedish, Norwegian and Danish languages, to human studies and publications from January 1990 to June 2020. The search was limited to this time period, as a previous systematic review has demonstrated that there is no relevant literature from before this date [17]. All articles remaining after the initial selection were obtained in full text for assessment by the other authors (EWJ, SB, HH, CJ, LJ, MP, MS, FW, EH). All authors independently assessed all the full-text articles (EWJ, SB, ME, HH, CJ, LJ, AL, MP, MS, FW, EH). Final inclusion was determined by consensus.

\section{Data collection process and data items}

Data were extracted by one author and verified by another. Information collected included: first author, year of publication, study country, study design, study scope, number of patients and controls, dropouts, study groups, body mass index (BMI), age, tobacco use, definition of breast hypertrophy, resection weight and outcomes according to the PICO.

\section{Statistical analysis}

The results of each article were tabulated per outcome (Tables 2, 3, 4, 5, 6, 7). When possible, data were pooled and subjected to meta-analysis using Review Manager (RevMan) and the Metan-command in Stata version 16. Random effects model using the method of DerSimonian and Laird, with the estimate of heterogeneity being taken from the inverse-variance fixed-effect model, was used. When only median and range was reported in the original studies, median was used as a proxy for mean and range divided by 6 was used a proxy to SD since mean $\pm 3 *$ SD covers about $99.7 \%$ of the population values. If SD was only reported for baseline this value was also used for follow-up. For most outcomes, meta-analysis was not possible due to heterogeneity in measures and follow-up time.

\section{Risk of bias in individual studies and across studies}

All included randomised and non-randomised controlled studies, as well as the qualitative study, were assessed regarding directness, risk of bias and precision, as described by the GRADE working group [25-28]. Checklists for assessing study quality, modified from the Swedish Agency for Health Technology Assessment and Assessment of Social Services (SBU) [29], were used. Certainty of evidence was assessed using the GRADE approach, as very low (GRADE $\oplus)$, low $(\mathrm{GRADE} \oplus \oplus)$, moderate (GRADE $\oplus \oplus \oplus)$, and high ( $\mathrm{GRADE} \oplus \oplus \oplus \oplus)$ [30]. High quality is defined as 'further research is very unlikely to change our confidence in the estimate of the effect', moderate quality as 'further research is likely to have an important impact on our confidence in the estimate of effect and may change the estimate', low as 'further research is very likely to have an important impact on our confidence in the estimate of effect and is likely to change the estimate', and very low as 'any estimate of effect is very uncertain' [30].

\section{Results}

Study selection

The literature search identified 1355 articles after removal of duplicates. Of these, 1257 articles were excluded after screening of abstracts. Another 44 articles were excluded 


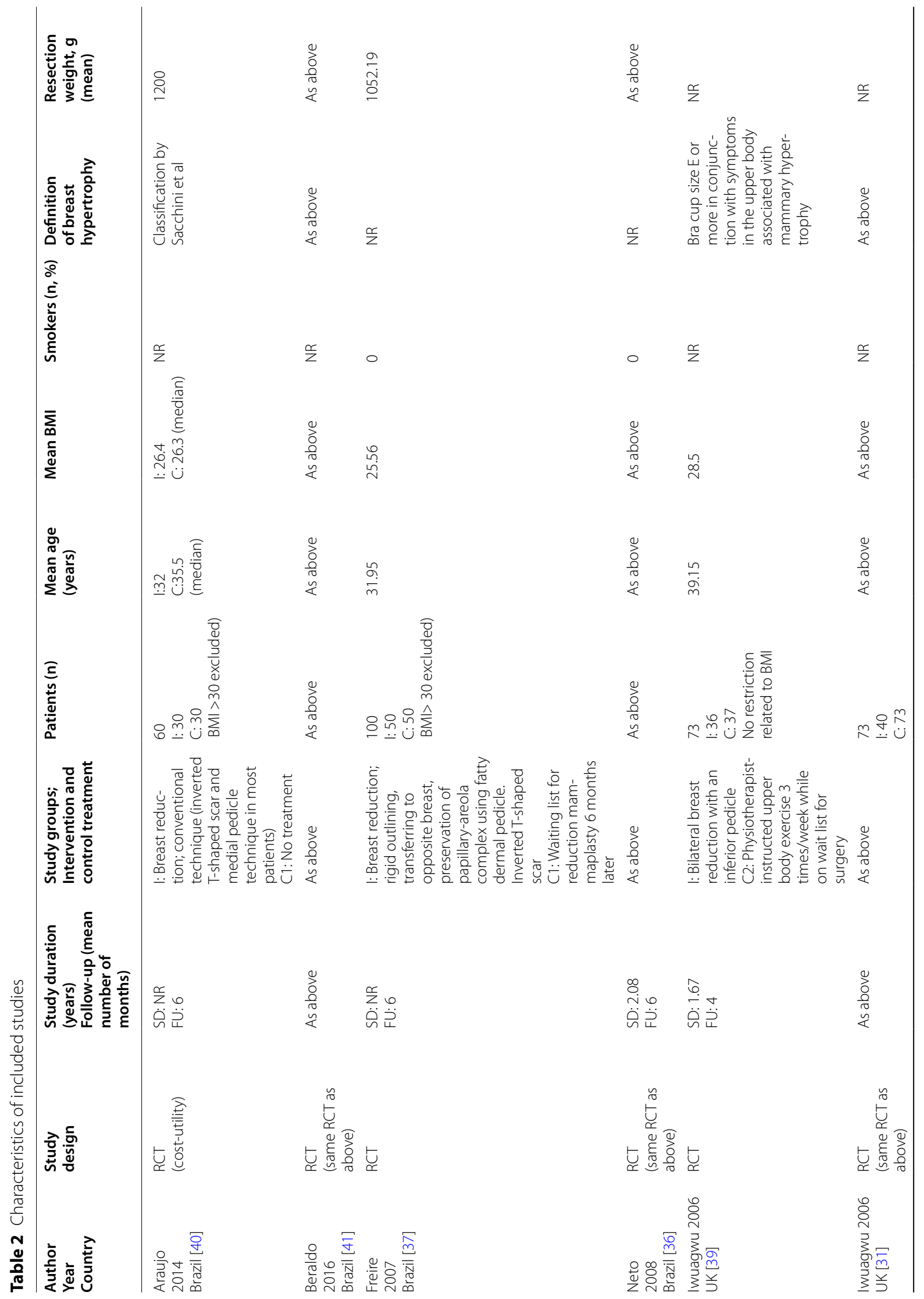




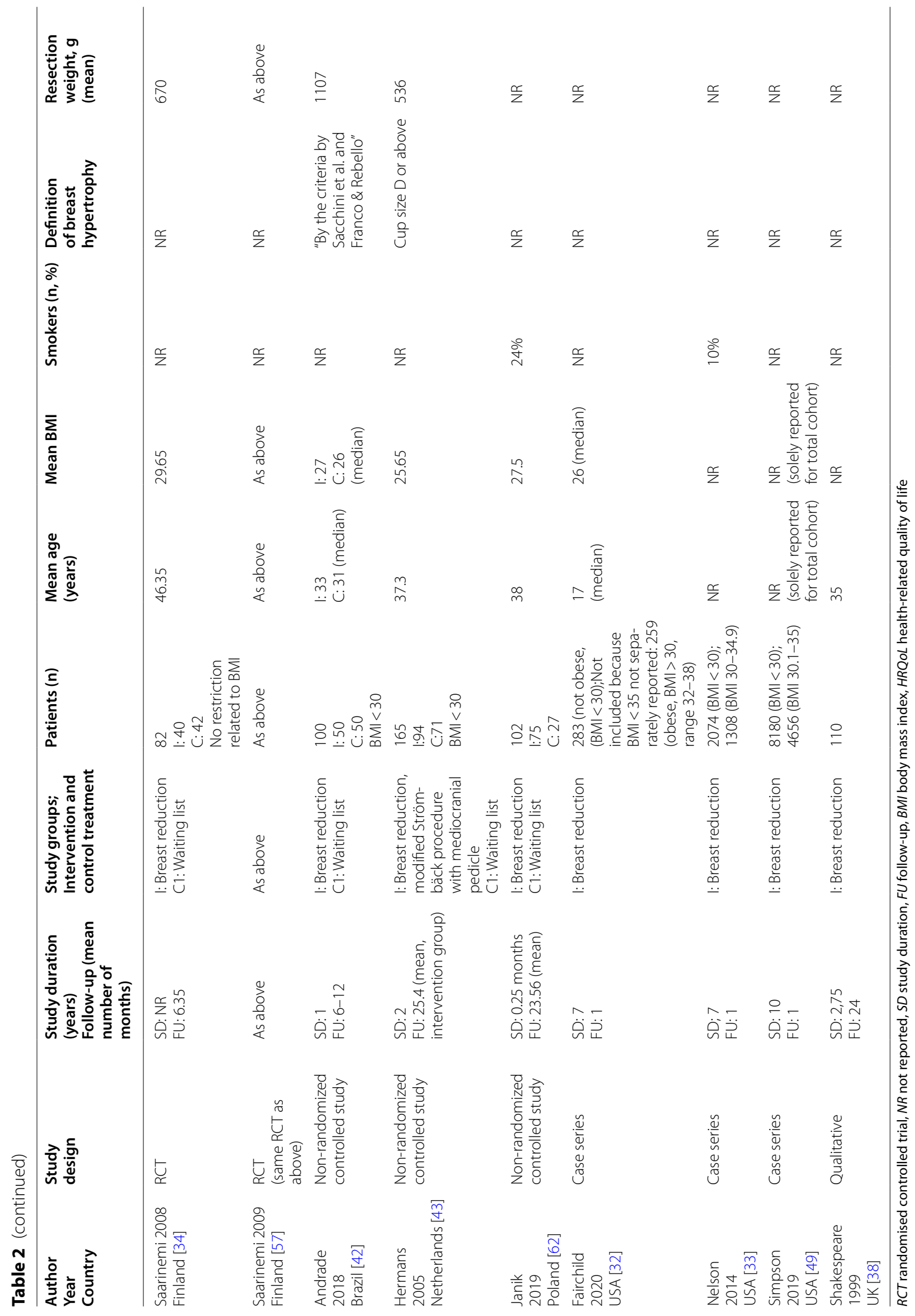




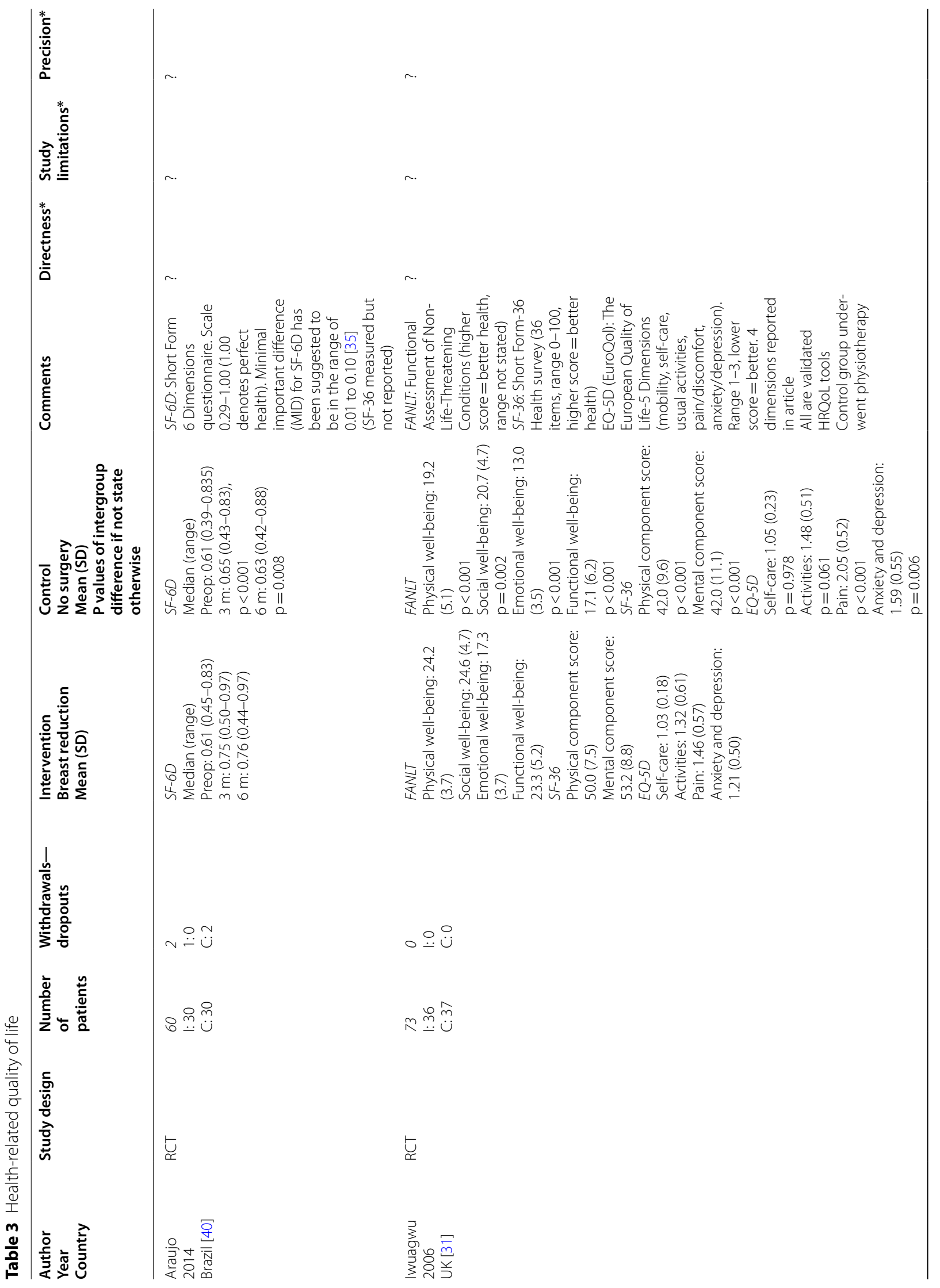




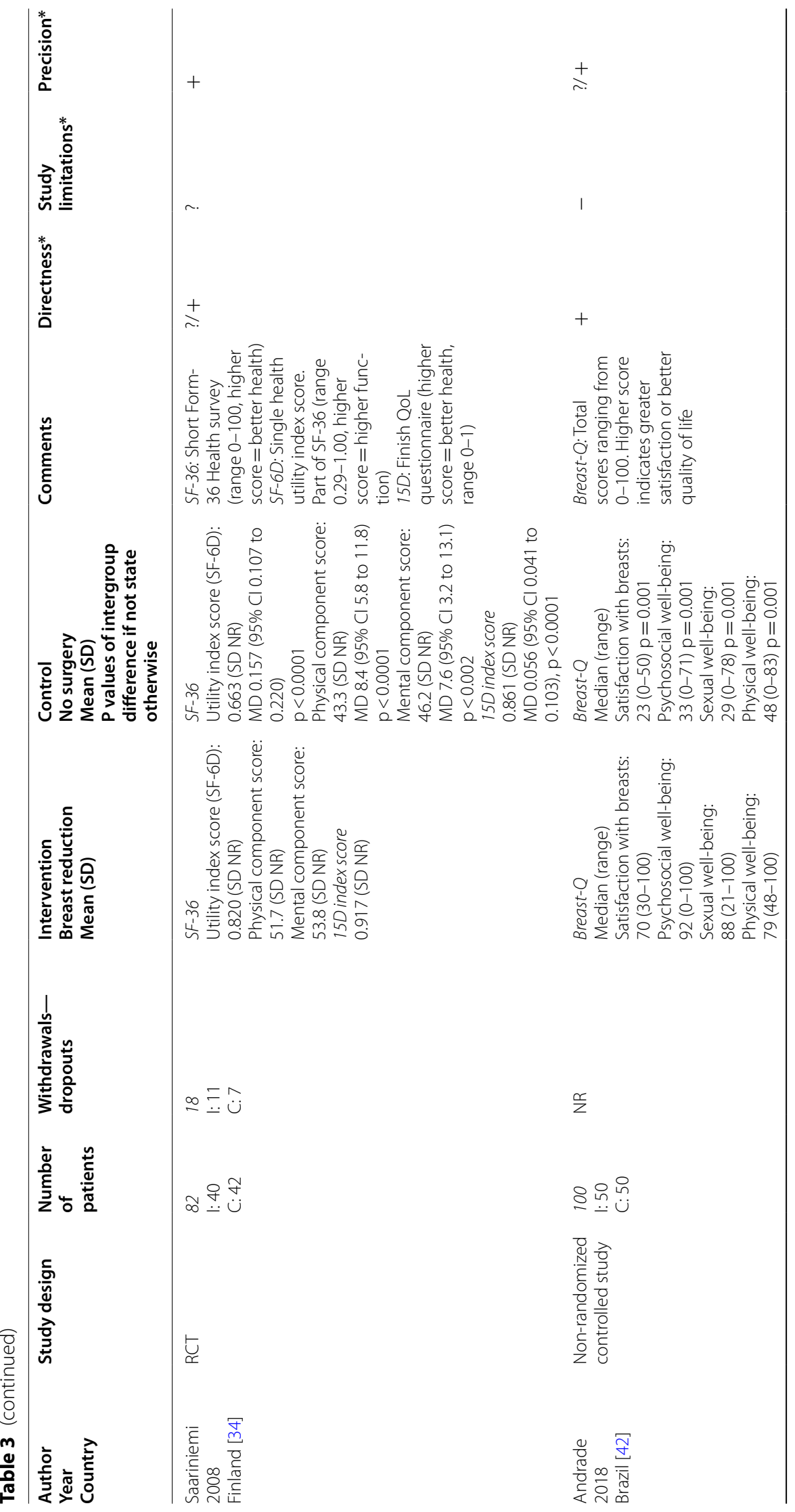




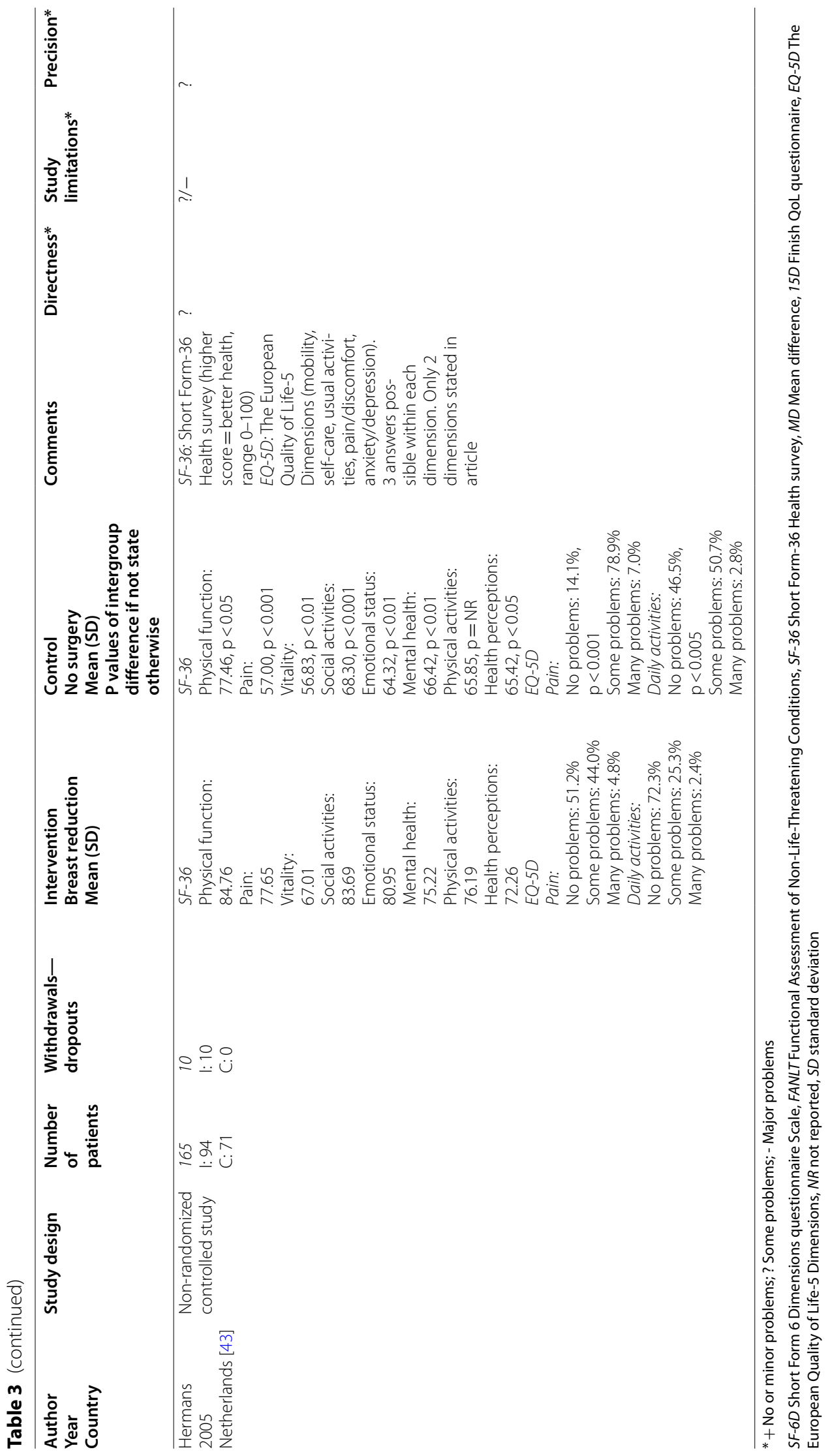


Table 4 Depression and anxiety

\begin{tabular}{|c|c|c|c|c|c|c|c|c|c|}
\hline $\begin{array}{l}\text { Author } \\
\text { Year } \\
\text { Country }\end{array}$ & $\begin{array}{l}\text { Study } \\
\text { design }\end{array}$ & $\begin{array}{l}\text { Number } \\
\text { of } \\
\text { patients }\end{array}$ & $\begin{array}{l}\text { Withdrawals- } \\
\text { dropouts }\end{array}$ & $\begin{array}{l}\text { Intervention } \\
\text { Breast } \\
\text { reduction } \\
\text { Mean (SD) }\end{array}$ & $\begin{array}{l}\text { Control } \\
\text { No surgery } \\
\text { Mean (SD) } \\
\text { P values of } \\
\text { intergroup } \\
\text { difference } \\
\text { if not state } \\
\text { otherwise }\end{array}$ & Comments & Directness* & $\begin{array}{l}\text { Study } \\
\text { limitations* }\end{array}$ & Precision* \\
\hline $\begin{array}{l}\text { Beraldo } \\
2016 \\
\text { Brazil [41] }\end{array}$ & $\mathrm{RCT}$ & $\begin{array}{l}\text { I: } 30 \\
\text { C: } 30\end{array}$ & $\begin{array}{l}\text { I: } 1 \\
\text { C: } 3\end{array}$ & $\begin{array}{l}\text { Depression } \\
\text { score (BDI) } \\
\text { Baseline: } 12.4 \\
\text { (9.0) } \\
3 \text { months: } \\
10.2 \text { (9.9) } \\
6 \text { months: } 7.2 \\
\text { (9.9) } \\
\text { Intragroup } \\
\text { change: Base- } \\
\text { line to } 3 \text { and } \\
6 \text { months } \\
p<0.001\end{array}$ & $\begin{array}{l}\text { Depression } \\
\text { score (BDI) } \\
\text { Baseline: } \\
13.2 \text { (9.6) } \\
p=0.89 \\
3 \text { months: } \\
13.0(8.5) \\
p=0.12 \\
6 \text { months: } \\
13.7(10.5) \\
p=0.01 \\
\text { Intragroup } \\
\text { change: } \\
\text { Baseline } \\
\text { to } 3 \text { and } \\
6 \text { months } \\
p=0.89\end{array}$ & $\begin{array}{l}\text { Beck Depression } \\
\text { Inventory (BDI) } \\
\text { (21 items, range } \\
0-63 \text {, higher score } \\
\text { indicates worse } \\
\text { depression) } \\
<10=\text { no or mini- } \\
\text { mal depression } \\
10-16=\text { mild } \\
\text { depression } \\
17-29=\text { moderate } \\
\text { depression } \\
30-63=\text { severe } \\
\text { depression } \\
\text { A MID of } 17.5 \% \text { of } \\
\text { the total score (11 } \\
\text { points) has been } \\
\text { suggested for BDI } \\
\text { [63] }\end{array}$ & $?$ & $?$ & $?$ \\
\hline $\begin{array}{l}\text { Iwuagwu } \\
2006 \\
\text { UK [39] }\end{array}$ & $\mathrm{RCT}$ & $\begin{array}{l}\text { I: } 36 \\
\text { C: } 37\end{array}$ & 0 & $\begin{array}{l}\text { Depression } \\
\text { score } \\
\text { Baseline: } 0.69 \\
\text { (0.30) } \\
4 \text { months: } \\
0.39(0.27) \\
\text { Proportion } \\
\text { depressed (no. } \\
\text { (\%)): } \\
\text { Baseline: } \\
\text { Normal score: } \\
28 \text { (78) } \\
\text { Borderline } \\
\text { score: } 6 \text { (17) } \\
\text { Abnormal } \\
\text { score: } 2 \text { (6) } \\
4 \text { months: } \\
\text { Normal score: } \\
\text { 34 (94) } \\
\text { Borderline } \\
\text { score: } 1 \text { (3) } \\
\text { Abnormal } \\
\text { score: } 1 \text { (3) }\end{array}$ & $\begin{array}{l}\text { Depression } \\
\text { score } \\
\text { Baseline: } \\
0.70(0.29) \\
4 \text { months: } \\
0.79(0.27) \\
\text { p<0.001 } \\
\text { Proportion } \\
\text { depressed } \\
\text { (no. (\%)): } \\
\text { Baseline: } \\
\text { Normal } \\
\text { score: } 27 \\
\text { (73) } \\
\text { Borderline } \\
\text { score: } 8 \\
\text { (22) } \\
\text { Abnormal } \\
\text { score: } 2(6) \\
4 \text { months: } \\
\text { Normal } \\
\text { score: } 25 \\
\text { (67) } \\
\text { Borderline } \\
\text { score: } 10 \\
\text { (27) } \\
\text { Abnormal } \\
\text { score: } 2(6) \\
\text { p<0.001 }\end{array}$ & $\begin{array}{l}\text { Hospital Anxiety } \\
\text { and Depression } \\
\text { Scale (HADS) (7 } \\
\text { items, range 0-21. } \\
\text { Higher score } \\
\text { indicates worse } \\
\text { depression) } \\
0-7 \text { 'normal' } \\
8-10 \text { 'borderline' } \\
\geq 11 \text { 'clinical } \\
\text { depression/anxi- } \\
\text { ety' } \\
\text { Depression scores } \\
\text { were transformed } \\
\text { to appropriate a } \\
\text { Gaussian distribu- } \\
\text { tion (1 + log 10) } \\
\text { A MID of 1.7 has } \\
\text { been suggested } \\
\text { for HADS [64] }\end{array}$ & $?$ & $?$ & $?$ \\
\hline
\end{tabular}


Table 4 (continued)

\begin{tabular}{|c|c|c|c|c|c|c|c|c|c|}
\hline $\begin{array}{l}\text { Author } \\
\text { Year } \\
\text { Country }\end{array}$ & $\begin{array}{l}\text { Study } \\
\text { design }\end{array}$ & $\begin{array}{l}\text { Number } \\
\text { of } \\
\text { patients }\end{array}$ & $\begin{array}{l}\text { Withdrawals- } \\
\text { dropouts }\end{array}$ & $\begin{array}{l}\text { Intervention } \\
\text { Breast } \\
\text { reduction } \\
\text { Mean (SD) }\end{array}$ & $\begin{array}{l}\text { Control } \\
\text { No surgery } \\
\text { Mean (SD) } \\
\text { P values of } \\
\text { intergroup } \\
\text { difference } \\
\text { if not state } \\
\text { otherwise }\end{array}$ & Comments & Directness* & $\begin{array}{l}\text { Study } \\
\text { limitations* }\end{array}$ & Precision* \\
\hline & & & & $\begin{array}{l}\text { Anxiety score } \\
\text { Baseline: } 9.1 \\
\text { (3.9) } \\
4 \text { months: } 5.0 \\
\text { (3.5) } \\
\text { Baseline: No } \\
\text { (\%) } \\
\text { Normal score: } \\
12 \text { (33) } \\
\text { Borderline } \\
\text { score: } 11 \text { (31) } \\
\text { Abnormal } \\
\text { score: } 13 \text { (36) }\end{array}$ & $\begin{array}{l}\text { Anxiety } \\
\text { score } \\
\text { Baseline: } \\
9.1 \text { (4.0) } \\
4 \text { months: } \\
9.6(3.8) \\
\text { p<0.001 } \\
\text { Baseline: } \\
\text { No (\%) } \\
\text { Normal } \\
\text { score: } 12 \\
\text { (32) } \\
\text { Borderline } \\
\text { score: } 11 \\
\text { (30) } \\
\text { Abnormal } \\
\text { score: } 14 \\
\text { (38) }\end{array}$ & & & & \\
\hline & & & & $\begin{array}{l}4 \text { months: } \\
\text { Normal score: } \\
30(83) \\
\text { Borderline } \\
\text { score: } 4(11) \\
\text { Abnormal } \\
\text { score: } 2 \text { (6) }\end{array}$ & $\begin{array}{l}4 \text { months: } \\
\text { Normal } \\
\text { score: } 10 \\
(28) \\
\text { Borderline } \\
\text { score: } 10 \\
(28) \\
\text { Abnormal } \\
\text { score: } 17 \\
(47) \\
\text { P<0.001 } \\
\text { MD } 4.6\end{array}$ & & & & \\
\hline \multirow[t]{2}{*}{$\begin{array}{l}\text { Saariniemi } \\
2009 \\
\text { Finland [57] }\end{array}$} & \multirow[t]{2}{*}{ RCT } & \multirow[t]{2}{*}{$\begin{array}{l}\text { l: } 40 \\
\text { C: } 42\end{array}$} & \multirow[t]{2}{*}{$\begin{array}{l}\text { I: } 11 \\
\text { C: } 7\end{array}$} & $\begin{array}{l}\text { RBDI } \\
\text { Depression } \\
\text { Baseline: } 5 \\
\text { (2.5-6.5) } \\
6 \text { months: } 0 \\
\text { (0.0-2.5) } \\
\text { Median (inter- } \\
\text { quartile) }\end{array}$ & $\begin{array}{l}R B D I \\
\text { Depression } \\
\text { Baseline: } 4 \\
(1.0-8.0) \\
6 \text { months: } 4 \\
(0.0-7.0) \\
p<0.01 \\
\text { Median } \\
\text { (interquar- } \\
\text { tile) }\end{array}$ & $\begin{array}{l}\text { RBDI: Raitasalo's } \\
\text { modification of } \\
\text { the short form of } \\
\text { the Beck Depres- } \\
\text { sion inventory } \\
\text { (range 0-39, lower } \\
\text { better) } \\
\text { 5-7: mild depres- } \\
\text { sion } \\
\text { 8-15: moderate } \\
\text { depression } \\
\text { >16: severe } \\
\text { depression }\end{array}$ & \multirow[t]{2}{*}{$? /+$} & \multirow[t]{2}{*}{$?$} & \multirow[t]{2}{*}{+} \\
\hline & & & & $\begin{array}{l}\text { Proportion } \\
\text { depressed (no. } \\
(\%)) \text { : } \\
\text { Baseline: } 16 \\
(55) \\
6 \text { months: } \\
2(7)\end{array}$ & $\begin{array}{l}\text { Proportion } \\
\text { depressed } \\
\text { (no. }(\%)) \text { : } \\
\text { Baseline: } 15 \\
\text { (43) } \\
6 \text { months: } \\
15(43) \\
p<0.01\end{array}$ & $\begin{array}{l}\text { Proportions: } \\
\text { Depressed=RBDI } \\
\text { depression } \\
\text { score }>4\end{array}$ & & & \\
\hline
\end{tabular}


Table 4 (continued)

\begin{tabular}{|c|c|c|c|c|c|c|c|c|c|}
\hline $\begin{array}{l}\text { Author } \\
\text { Year } \\
\text { Country }\end{array}$ & $\begin{array}{l}\text { Study } \\
\text { design }\end{array}$ & $\begin{array}{l}\text { Number } \\
\text { of } \\
\text { patients }\end{array}$ & $\begin{array}{l}\text { Withdrawals- } \\
\text { dropouts }\end{array}$ & $\begin{array}{l}\text { Intervention } \\
\text { Breast } \\
\text { reduction } \\
\text { Mean (SD) }\end{array}$ & $\begin{array}{l}\text { Control } \\
\text { No surgery } \\
\text { Mean (SD) } \\
\text { P values of } \\
\text { intergroup } \\
\text { difference } \\
\text { if not state } \\
\text { otherwise }\end{array}$ & Comments & Directness* & $\begin{array}{l}\text { Study } \\
\text { limitations* }\end{array}$ & Precision* \\
\hline & & & & $\begin{array}{l}\text { Anxiety } \\
\text { No. (\%) } \\
\text { Baseline: } 18 \\
(62) \\
6 \text { months: } 3 \\
(10)\end{array}$ & $\begin{array}{l}\text { Anxiety } \\
\text { No. (\%) } \\
\text { Baseline: } 18 \\
\text { (51) } \\
6 \text { months: } \\
12 \text { (34) } \\
p=0.04 \\
\text { MD } 9\end{array}$ & & & & \\
\hline
\end{tabular}

* + No or minor problems; ? Some problems; - Major problems

$B D I$ Beck Depression Inventory, HADS Hospital Anxiety and Depression Scale, RBDI Raitasalo's modification of the short form of the Beck Depression Inventory

when they had been read in full text (Fig. 1). The 54 fulltext articles left after this first selection were sent to all authors, and 15 articles were finally included in the review (Table 2). The excluded articles, with reasons for exclusion, are presented in Additional file 2.

\section{Study characteristics}

Of the fifteen included articles, four were RCTs (reported in eight papers), three were non-randomised controlled studies, three were case series, and one was a qualitative study (Table 2). The majority of the included studies compared surgical intervention with no treatment $(\mathrm{C} 1)$ and one study [31] with physiotherapy ( $\mathrm{C} 2$, non-surgical treatment).

\section{Risk of bias within and across studies}

The RCTs had serious study limitations, indirectness, and/or imprecision. Methodological issues included unclear definition of breast hypertrophy, short follow-up, lack of blinding of patients or surgeons, control groups composed of patients waiting for a breast reduction, and a lack of inter-group comparisons. Effects were measured using validated patient-reported outcome measures. The non-randomised controlled studies had some study limitations in terms of poor evaluation of potential confounding, adherence, dropouts, and unclear definitions of breast hypertrophy. The qualitative study was assessed as being of moderate quality.

\section{Mortality and complications}

Mortality was reported in three case series $(n=104,565)$, all based on the same registry, NSQIP; thus, slightly overlapping. One death was reported in the population with BMI $>30$, not included in this review [32]. Three RCTs, one non-randomised controlled study and three cases series, based on register data, reported surgical complications (Additional file 3). Reporting standards were heterogeneous, as complications were not predefined, and no information was given about when, how, or by whom they were diagnosed. The reported frequencies of major complications after breast reduction, such as venous thromboembolism [33, 34], varied from 2.4 to $14 \%$, and frequencies of minor complications, such as surgical site infection and delayed wound healing, from 2.4 to $69 \%$. Two of the included studies showed that increased BMI was a risk factor for complications [32, 33].

\section{Health-related quality of life}

Health-related quality of life was reported in three RCTs and two non-randomised controlled studies, using both generic (SF-6D, and SF-36) and disease-specific (BREAST-Q) questionnaires (Table 3). HRQoL was improved after breast reduction in all included studies, compared with no surgery. Meta-analyses (Figs. 2, $3,4)$ performed for SF-6D and SF-36 scores, showed a weighted mean difference for SF-6D of 0.14 (95\% CI $0.10-0.17) 6$ months after surgery, implying a clinically relevant difference in HRQoL, compared with the previously suggested minimal important difference (MID) [35] (Table 3). In summary, breast reduction compared with no surgery may result in a clinically relevant improvement in HRQoL in women with breast hypertrophy (low certainty of evidence, GRADE $\oplus \oplus$ ).

\section{Depression and anxiety}

Depressive symptoms were reported in three RCTs $(n=215)$ and symptoms of anxiety in two RCTs $(n=155)$, using different validated assessment tools and scores (Table 4). Postoperative (4-6 months) depressive symptom rates were consistently lower in women undergoing 
Table 5 Sexually-related outcomes

\begin{tabular}{|c|c|c|c|c|c|c|c|c|c|}
\hline $\begin{array}{l}\text { Author } \\
\text { Year } \\
\text { Country }\end{array}$ & Study design & $\begin{array}{l}\text { Number } \\
\text { of } \\
\text { patients }\end{array}$ & $\begin{array}{l}\text { Withdrawals- } \\
\text { dropouts }\end{array}$ & $\begin{array}{l}\text { Intervention } \\
\text { Breast reduction } \\
\text { Mean (SD) }\end{array}$ & $\begin{array}{l}\text { Control } \\
\text { No surgery } \\
\text { Mean (SD) } \\
\text { P values of } \\
\text { intergroup } \\
\text { difference } \\
\text { if not state } \\
\text { otherwise }\end{array}$ & Comments & Directness* & $\begin{array}{l}\text { Study } \\
\text { limitations* }\end{array}$ & Precision* \\
\hline $\begin{array}{l}\text { Beraldo } \\
2016 \\
\text { Brazil [41] }\end{array}$ & $\mathrm{RCT}$ & $\begin{array}{l}\text { I: } 30 \\
\text { C: } 30\end{array}$ & $\begin{array}{l}\text { I: } 1 \\
C: 3\end{array}$ & $\begin{array}{l}\text { Sexual function } \\
\text { Baseline: } 24.7(8.8) \\
6 \text { months: } 27.5 \\
(6.9)\end{array}$ & $\begin{array}{l}\text { Sexual function } \\
\text { Baseline: } 23.9 \\
(9.6) \\
p=0.96 \\
6 \text { months: } 22.5 \\
(9.3) \\
p<0.001 \\
\text { MD } 5.0\end{array}$ & $\begin{array}{l}\text { Female Sexual } \\
\text { Function Index } \\
\text { (FSFI). The } \\
\text { questionnaire } \\
\text { includes } 19 \\
\text { questions on } \\
\text { sexual activity } \\
\text { during the last } \\
4 \text { weeks. It has } \\
6 \text { domains: } \\
\text { desire, arousal, } \\
\text { lubrication, } \\
\text { orgasm, sat- } \\
\text { isfaction, and } \\
\text { discomfort/ } \\
\text { pain. A higher } \\
\text { score means a } \\
\text { better function. } \\
\text { A total score } \\
\text { of } 26.55 \text { or } \\
\text { less indicates } \\
\text { sexual dysfunc- } \\
\text { tion } \\
\text { A MID of } 4.2 \\
\text { has been sug- } \\
\text { gested for FSFI } \\
\text { [65] }\end{array}$ & $?$ & $?$ & $?$ \\
\hline $\begin{array}{l}\text { Andrade } \\
2018 \\
\text { Brazil [42] }\end{array}$ & $\begin{array}{l}\text { Non-rand- } \\
\text { omized con- } \\
\text { trolled study }\end{array}$ & $\begin{array}{l}\text { I: } 50 \\
\text { C: } 50\end{array}$ & $N R$ & $\begin{array}{l}\text { Sexual well-being } \\
6 \text { months-1 year: } \\
88 \text { ( } 21-100) \\
\text { median (range) }\end{array}$ & $\begin{array}{l}\text { Sexual well- } \\
\text { being } \\
29(0-78) \\
\text { median (range) } \\
p=0.001 \\
\text { MD } 66\end{array}$ & $\begin{array}{l}\text { Sexual well- } \\
\text { being domain } \\
\text { of BREAST-Q } \\
\text { (reduction/ } \\
\text { mastopexy } \\
\text { module) } \\
\text { Score 0-100, } \\
\text { a higher score } \\
\text { means better } \\
\text { outcome } \\
\text { Baseline values } \\
\text { are not given }\end{array}$ & + & - & ?/+ \\
\hline \multirow[t]{3}{*}{$\begin{array}{l}\text { Janik } \\
2019 \\
\text { Poland [62] }\end{array}$} & \multirow[t]{3}{*}{$\begin{array}{l}\text { Non-rand- } \\
\text { omized con- } \\
\text { trolled study }\end{array}$} & \multirow[t]{3}{*}{$\begin{array}{l}\text { l: } 75 \\
\text { C: } 27\end{array}$} & \multirow[t]{3}{*}{$N R$} & $\begin{array}{l}\text { Sexual quality } \\
\text { of life } \\
12-36 \text { months: } \\
76.7 \text { (11.6) } \\
\text { (mean follow-up } \\
23.6 \text { months) }\end{array}$ & $\begin{array}{l}\text { Sexual quality } \\
\text { of life } \\
64.4(13.7) \\
p<0.01 \\
\text { MD } 12\end{array}$ & $\begin{array}{l}\text { Sexual Quality } \\
\text { of Life-Female } \\
\text { (SQoL-F): } 18 \\
\text { items, each } \\
\text { scored from } \\
\text { 1-6, total score } \\
\text { 18-108 } \\
\text { Higher score } \\
\text { better }\end{array}$ & \multirow[t]{3}{*}{+} & \multirow[t]{3}{*}{-} & \multirow[t]{3}{*}{ - } \\
\hline & & & & $\begin{array}{l}\text { Sexual function } \\
12-36 \text { months: } \\
27.4(9.1)\end{array}$ & $\begin{array}{l}\text { Sexual function } \\
\text { Pre-operative: } \\
21 \text { (11.4) } \\
p=0.03\end{array}$ & $\begin{array}{l}\text { Female Sexual } \\
\text { Function Index } \\
\text { (FSFI). Higher } \\
\text { score better }\end{array}$ & & & \\
\hline & & & & $\begin{array}{l}\text { Sexual well-being } \\
\text { 12-36 months: } \\
72(14)\end{array}$ & $\begin{array}{l}\text { Sexual well- } \\
\text { being } \\
\text { Pre-operative: } \\
39.3(14.5) \\
p<0.01\end{array}$ & $\begin{array}{l}\text { Sexual well- } \\
\text { being domain } \\
\text { of BREAST-Q } \\
\text { (reduction/ } \\
\text { mastopexy } \\
\text { module). } \\
\text { Baseline values } \\
\text { not reported }\end{array}$ & & & \\
\hline
\end{tabular}


Table 5 (continued)

* + No or minor problems; ? Some problems; - Major problems

breast reduction compared with no treatment or physiotherapy. The postoperative anxiety symptoms were measured after four to six months and were significantly lower in women who had undergone breast reduction in both studies. In summary, breast reduction, compared with no surgery, may result in a clinically relevant reduction in depressive and anxiety symptoms, in women with breast hypertrophy (low certainty of evidence, GRADE $\oplus \oplus$ ).

\section{Sexuality-related outcomes}

Sexuality-related outcomes were reported in one RCT and two non-randomised controlled studies $(n=262)$, using different instruments (Table 5). Sexual function, sexual well-being, and sexual quality of life were significantly improved after breast reduction compared with no surgery. In summary, sexuality-related outcomes may be significantly improved by breast reduction, compared with no surgical intervention (low certainty of evidence, GRADE $\oplus \oplus)$.

\section{Work ability and sick leave}

Work ability and sick leave were not reported in any of the included studies.

\section{Physical function}

Physical function after breast reduction compared with no surgery, was reported in two RCTs and two non-randomised controlled studies $(n=447)$ (Table 6). One RCT reported physical function in two papers [36, 37]. Statistically significant improvement in physical function after surgery was reported in the RCTs, with a follow-up time of 6 months. Significant intergroup improvement was reported in the non-randomised controlled studies regarding physical wellbeing, physical function and daily activities after surgery. In conclusion, it is uncertain whether breast reduction compared with no surgery affects physical function in women with breast hypertrophy (very low certainty of evidence, GRADE $\oplus$ ).

\section{Pain}

Three RCTs and one non-randomised controlled study $(n=420)$ reported pain (Table 7$)$, measured with different instruments. Pain was significantly reduced in all studies. In summary, breast reduction compared with no surgery may result in a clinically relevant reduction of pain in women with breast hypertrophy (low certainty of evidence, GRADE $\oplus \oplus)$..

\section{Patient experiences of a breast reconstruction}

One qualitative study including 50 patients was identified [38]. Most of the patients reported an increased physical activity after the operation and believed that the operation had changed their lives to the better. Nonetheless, a few patients reported a deterioration in self-image and quality of life and one patient expressed regret. Some patients were unsatisfied or distressed with the scarring (Additional file 4).

\section{Definitions of breast hypertrophy and indications for a breast reduction}

As regards definitions, three studies used the Sacchini criteria, two studies used bra cup size, and 10 studies did not report how they defined breast hypertrophy (Table 2). One study reported that a bra size of $\mathrm{E}$ or more in combination with 'symptoms in the upper body associated with mammary hypertrophy' constituted an indication for surgery [39]. None of the other studies specifically reported indications for a breast hypertrophy.

\section{Discussion}

The aim of this review was to examine the risks and benefits of breast reduction in women with breast hypertrophy, with an underlying focus on identifying specific indications for surgery in the public healthcare system.

\section{Methodological limitations of the included studies}

Several methodological limitations were identified in all included studies. Main issues included a lack of, or the use of non-validated, definitions of breast hypertrophy and of complications, a potentially biased control group, lack of blinding, a short follow-up, and insufficient reporting of inter-group results.

The main problem with the lack of definitions of breast hypertrophy and indications for breast reductions in the studies is that it is difficult to evaluate effects of treatment when the condition is not adequately defined. Moreover, not all of the studies reported the resected amount of breast tissue, further complicating the evaluation of the effects of the intervention in relation to the severity of breast hypertrophy. There are a number of limitations regarding the use of unvalidated breast measurements, such as bra size and the Sacchini criteria, that were used in the few studies [39-43] in this review that reported their definition. Firstly, there are no conclusive studies determining what volume/weight, in relation to body build, that gives rise to physical and/or psychosocial symptoms, and symptom relief does not seem to be correlated to the amount of tissue resected [22, 44]. 


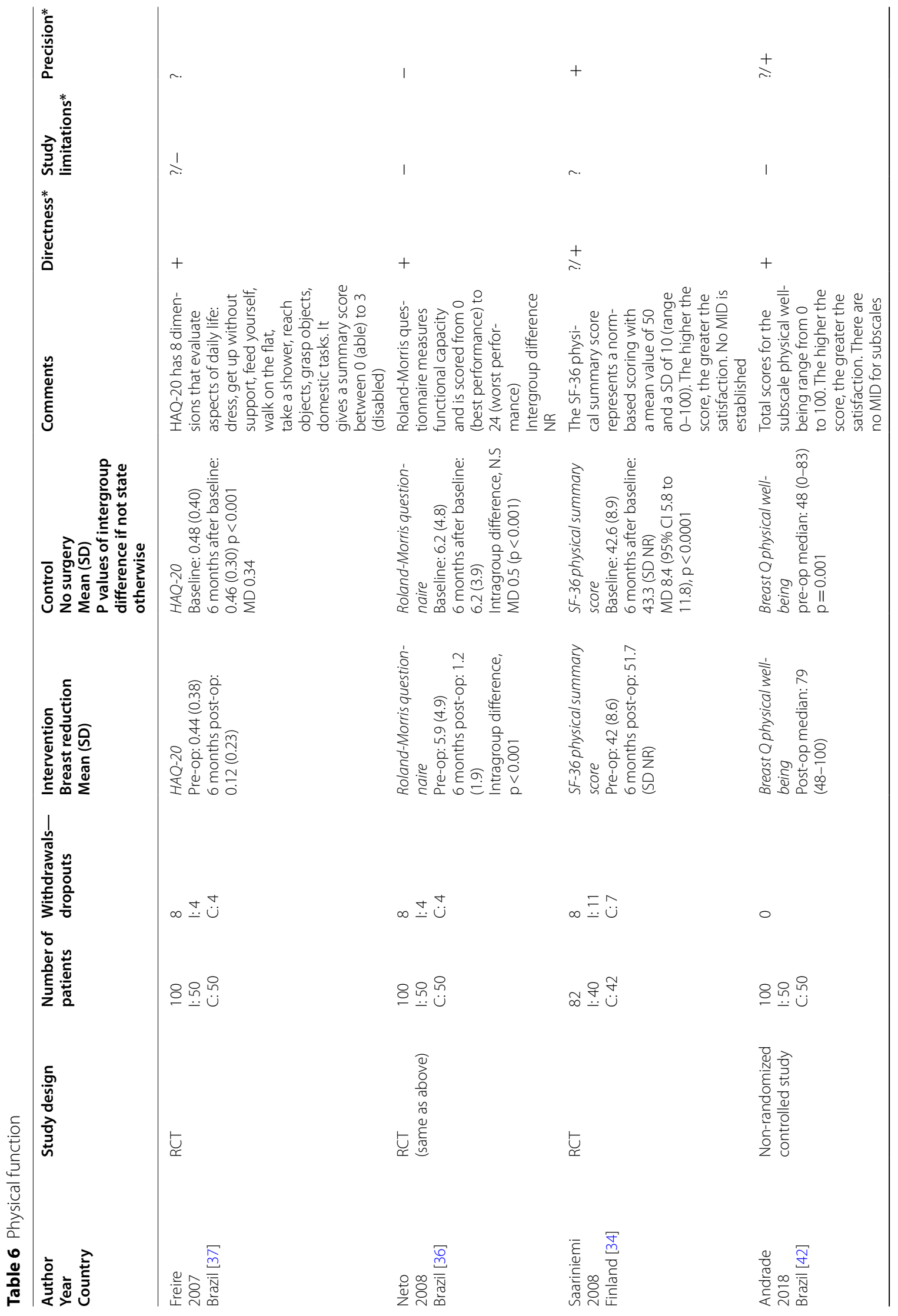




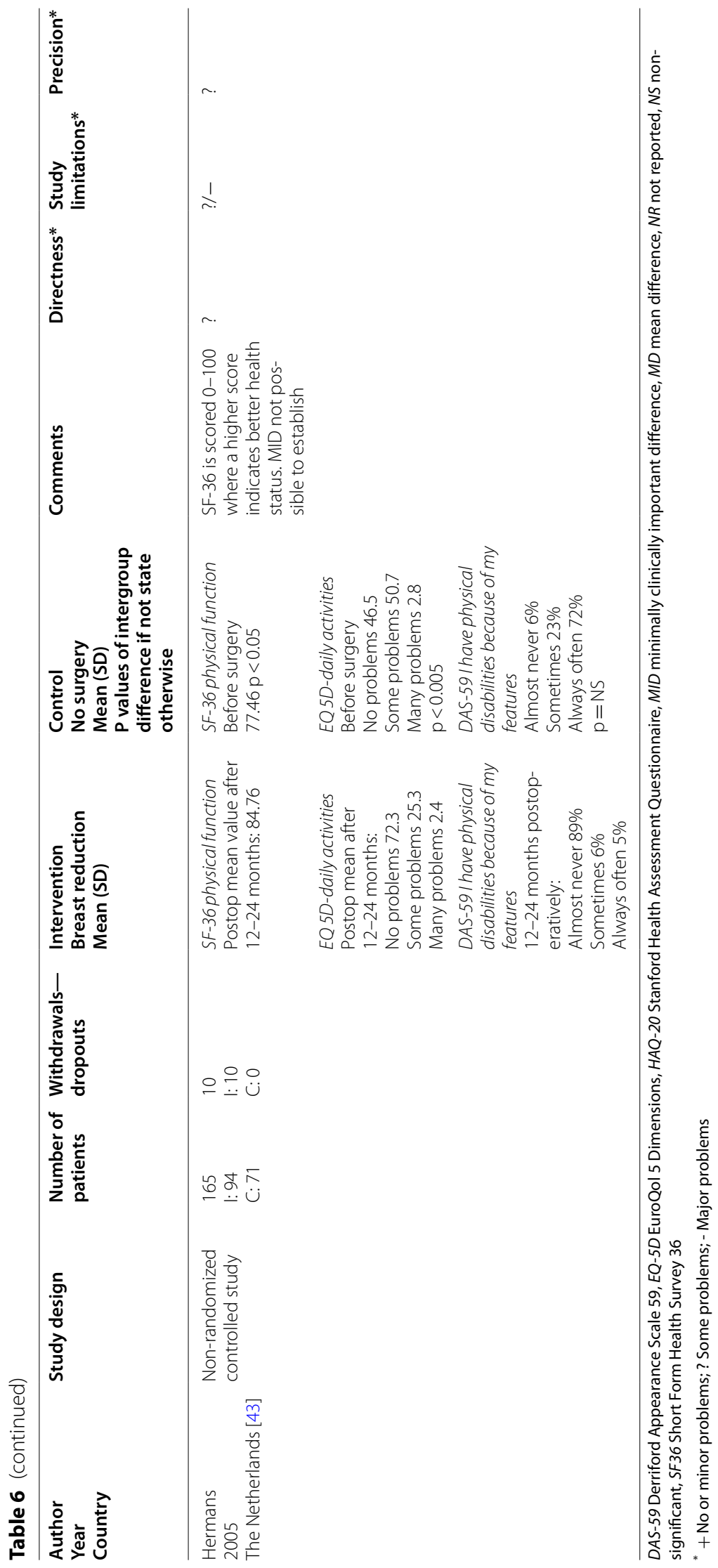




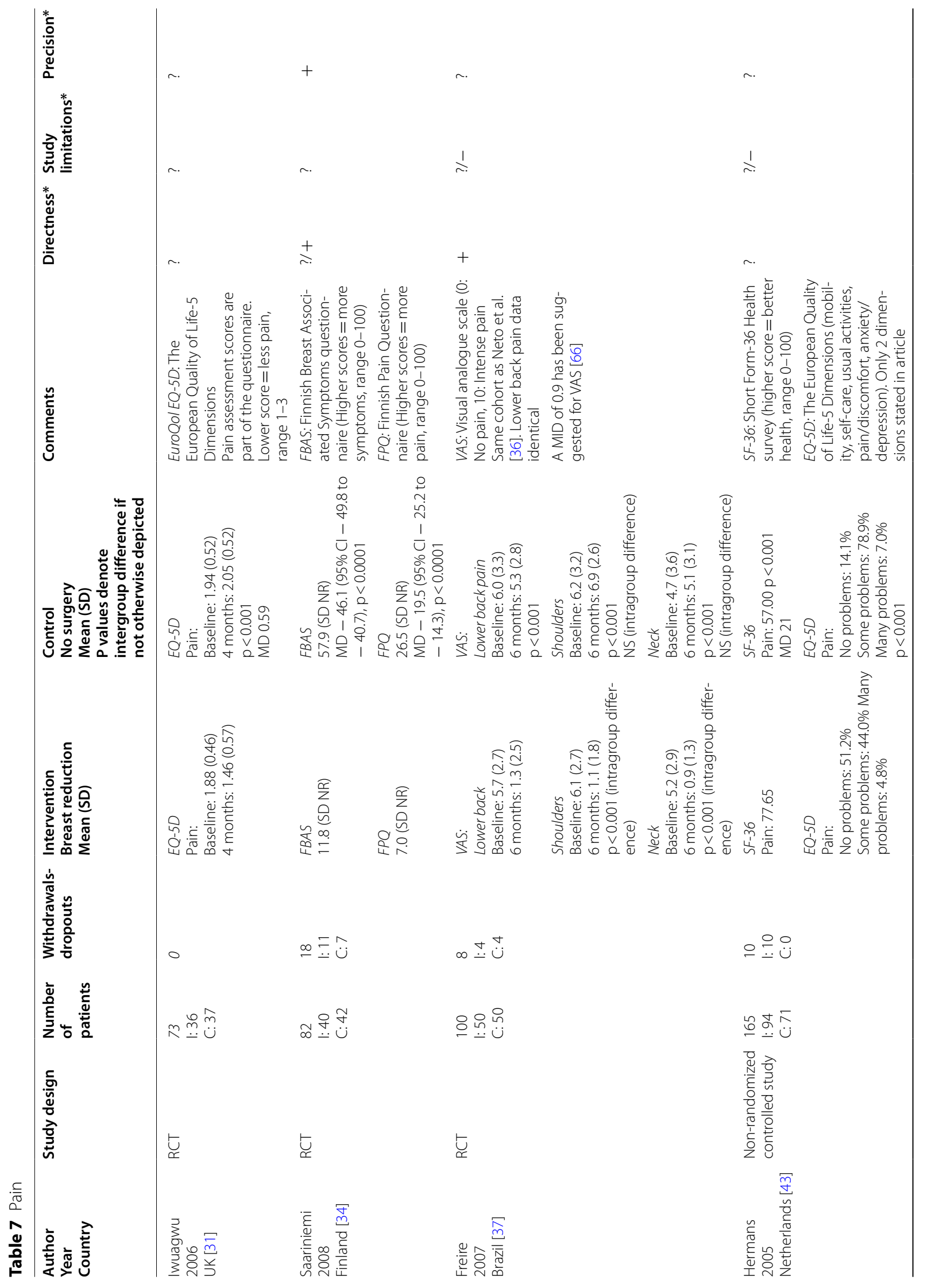




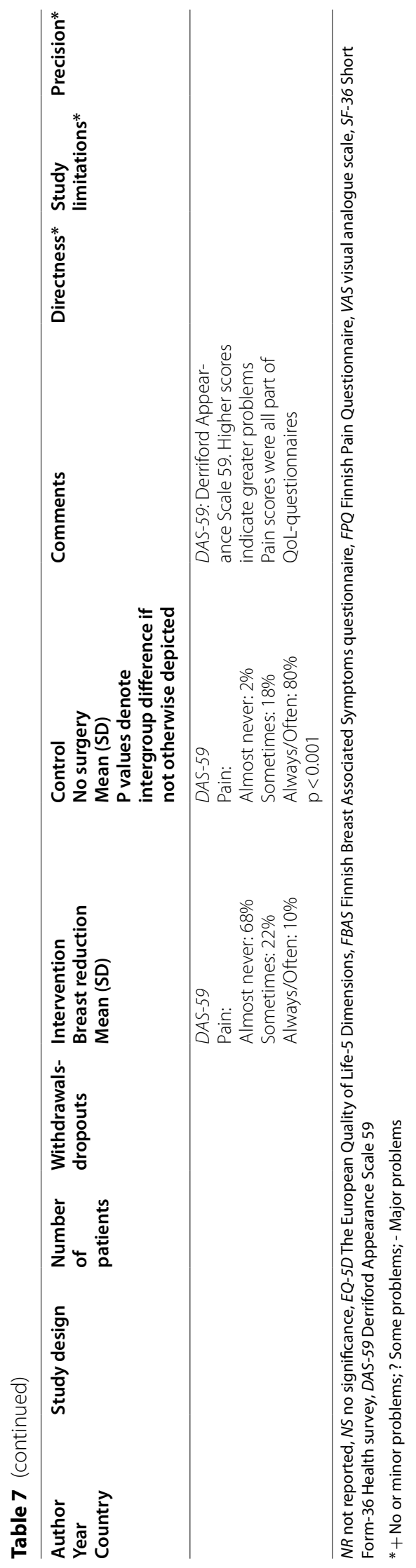




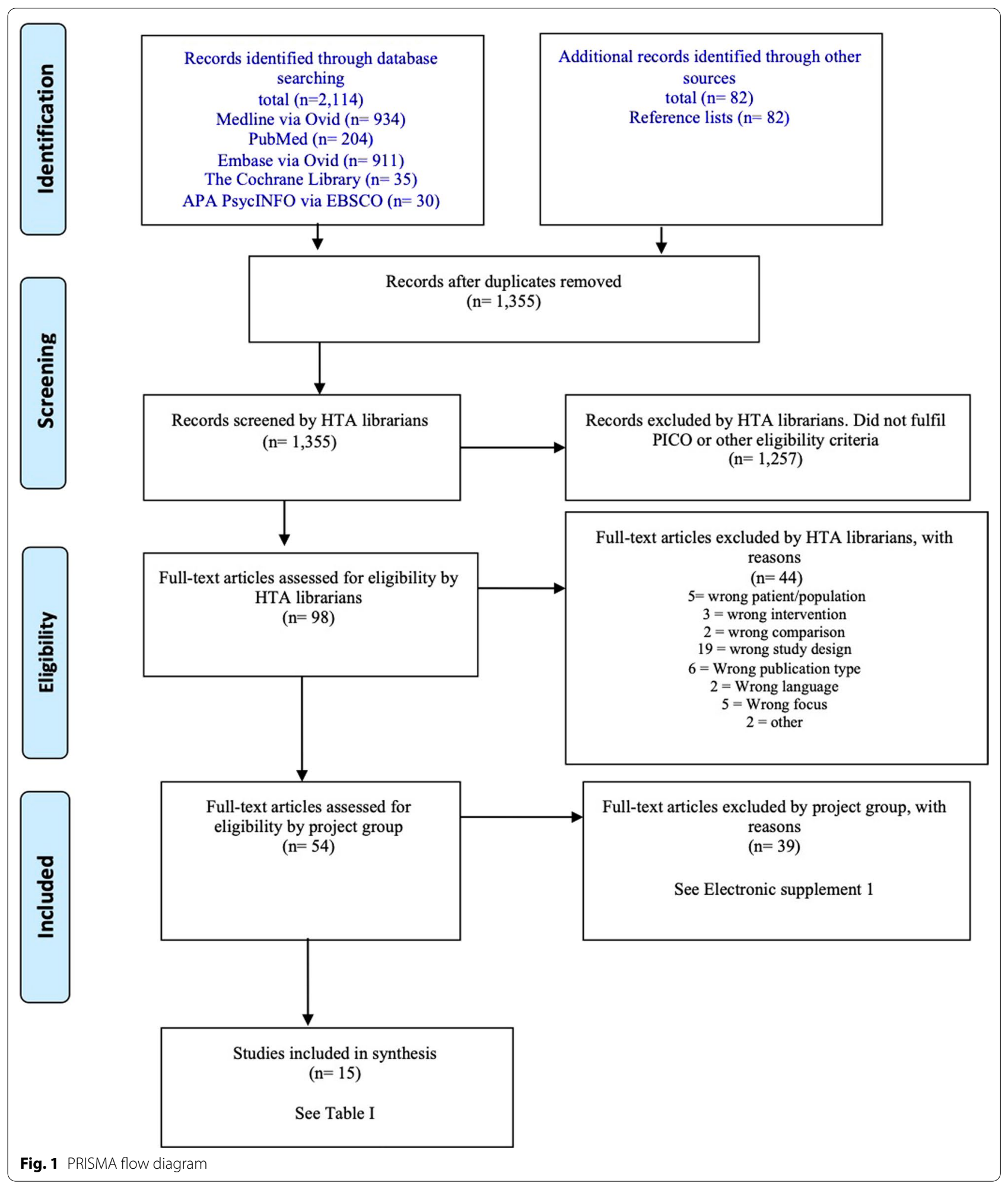

Secondly, the relationship between breast volume and breast weight is not clear-cut as different breasts have different density. The ratio between adipose tissue and breast tissue varies according to genetics and hormonal status and breast tissue weighs more than adipose tissue. Thirdly, breast size measurements are uncertain $[45,46]$. 


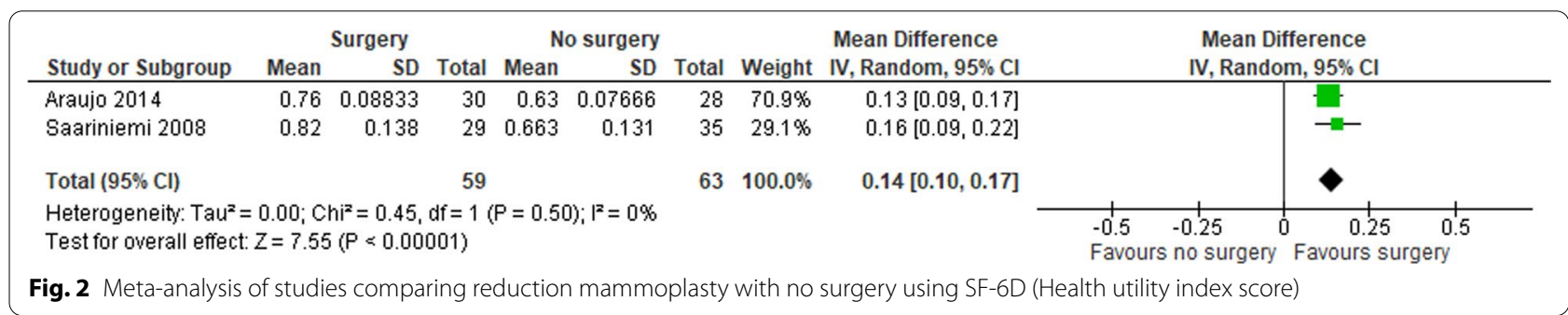

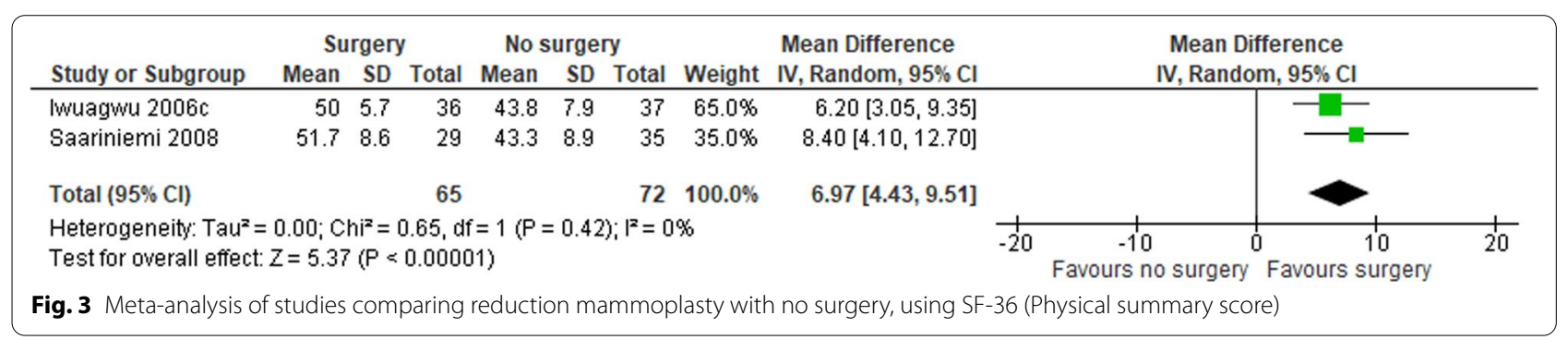

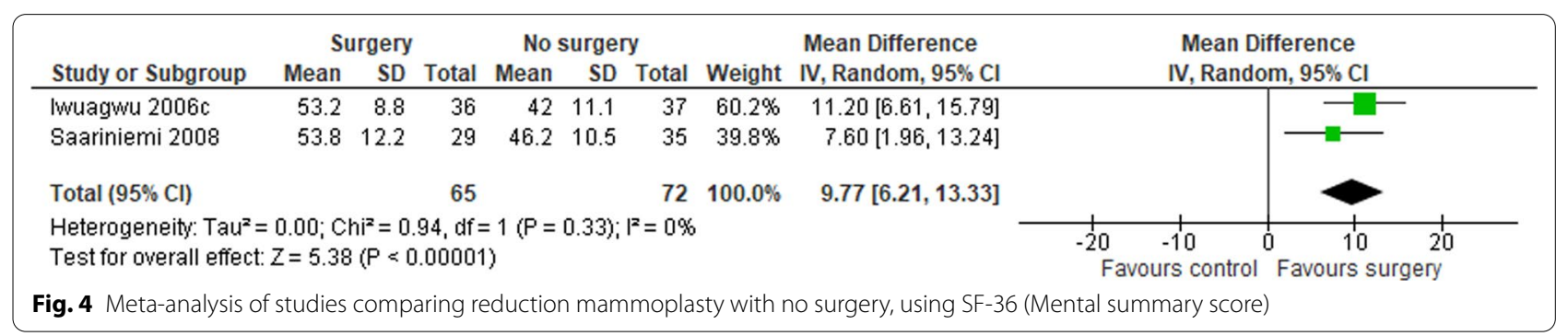

As regards, the use of cup sizes, they are not standardised; for example, one brand's D cup might equal another brand's $C$ cup. The cup size is often based on the difference in breast circumference and rib cage circumference; that is, a difference of one inch $(2.54 \mathrm{~cm})$ constitutes an A cup, two inches a B cup, etc. and consequently the actual volume of the cup is substantially different depending on the circumference of the rib cage. Moreover, the model of the bra, for example if it covers the entire or only part of the breast, creates different 'volumes'. Finally, there is a considerable difference in how women want their bra to fit; that is, women with identical breast volume might wear different bra sizes [47]. In brief, it is unclear which conditions have actually been treated in the included studies.

None of the included studies stated how complications were defined and whether they had been registered in a systematic and prospective fashion or not. Similar methodological problems have been seen previously in studies on breast reduction, where most studies only register surgical site complications in an undefined way leading to an underestimation of overall complication rates [48]. In one of few publications [48] on breast reduction where complications were classified according to a validated system, Clavien-Dindo, the complication frequency was 63\%, albeit retrospectively registered. A prospective approach could give an even higher complication frequency. The most common type of complication (46\%) was wound healing complications [48]. The study by Winter and associates [48] was not included in this review as the number of reported patients were 486, and the inclusion requirement of $>1000$ patients for case series was therefore not met. In this review, the lower complication rates are from publications reporting figures from the NSQIP registry $[32,33,49]$. In the registry, wound complications are defined as 'superficial infection, deep wound infection, deep or organ space infection, and wound dehiscence' [49]. In Winter et al's study [48], the rate of such wound complications was $9 \%$, and the rate of milder wound complications, not requiring an intervention, such as antibiotics or debridement, was $48 \%$. Indeed, the studies included in this report with higher complication rates seem to have included all types of wound complications. Hence, complications are common but reported 
frequencies are dependent on how complications are defined and classified, explaining the wide range of frequencies observed in the present review.

In all included RCTs, patients who wanted a breast reduction were randomised either to breast reduction or to a waiting list for such surgery. Therefore, all the patients were likely biased towards a wish for a breast reduction and all the controls knew that they would receive a breast reduction eventually. It can be discussed whether such patients represent an adequate untreated control group. The practice also implies that neither the patients nor the surgeons were blinded.

Another issue limiting the directness of the results, is the short follow-up time in the included studies. According to basic plastic surgical principles, a final result can never be evaluated before at least a year has passed [50]. Most of the included studies had a follow-up time of less than one year, and therefore the measured effects might not represent the final outcome of surgery. Patients who are treated with surgery they have requested themselves, initially experience a positive effect of the surgery that might diminish over time [51]. Moreover, two of the four RCTs were conducted in the same country which might limit the generalisability of the results as cultural norms [52], and perceived need for breast reduction, might be different in other parts of the world.

\section{Discussion of current evidence}

Our review shows that complications are frequent after breast reduction. None of the included studies specifically reported the impact of different breast volumes on the effect and safety of breast reconstruction. However, the case series on complications clearly showed that a BMI equal to or higher than 30 increases the risk for complications by three-fold [32]. Moreover, the most serious complications, such as pulmonary embolism [34] and death [32], occurred in patients with a high BMI. Nonetheless, even though a high BMI clearly increases the risk for complications, there is no evidence to suggest where the exact BMI limit should be. None of the included studies specifically included an analysis of other risk factors for complications, such as smoking [53]. However, the high frequency of wound healing complications in all of the included studies could indicate that all risk factors for wound healing problems should be eliminated.

Regarding effects, breast reduction may improve HRQoL and may reduce depressive symptoms, anxiety symptoms, and pain, compared with no surgery. However, such effect can also be seen when a breast reduction is performed for aesthetic purposes [14, 15, 54]. In this context, it is unclear how such patient-reported outcomes improvement should be valued, and how patients suffering due to appearance related factors should be differentiated from patients with a mere preference for plastic surgery $[16,55]$. Moreover, little is known about the long-term effect of plastic surgery on HRQoL, depression and anxiety [56]. In addition, some of the effects, such as the effect of breast reduction on depression, should be interpreted with caution, as the observed baseline values generally indicated no or mild depression $[39,41,57]$. A total of five health economic articles [40, 58-61] were identified in the literature search but only one [40] of them fulfilled the eligibility criteria for inclusion. The studies were all based on studies with small sample sizes, assessing QALY benefits by the intra-individual changes in HRQoL (i.e. lacking control group) and making the optimistic assumption that the HRQoL benefits would last the rest of the lifetime.

The effects seen in this review on HRQoL, depressive symptoms, and anxiety after breast reduction illustrate that breast hypertrophy gives rise to more symptoms than back pain and functional problems, which might indicate that a volume/size requirement is too crude a measure to decide which patients will benefit from a breast reduction and should be granted an operation in the public healthcare system. Moreover, there are no reports on which volumes/weights give rise to physical symptoms in relation to body build and other factors, further strengthening that a volume/size definition, on its own, seems inadequate to predict which patients benefit the most from a breast reduction. In brief, to create evidence-based guidelines for which patients should be granted a breast reduction in the public healthcare system, more studies are needed on the definition of breast hypertrophy and the health care need it gives rise to, as well as on the effect of treatment.

\section{Conclusions}

There are few studies and a lack of high-quality studies that evaluate the results of breast reduction and include a definition of breast hypertrophy. A breast reduction seems to have positive psychological and physical effects for women, but it is unclear which women benefit the most and which women should be offered a breast reduction in the public healthcare system. Currently, there is large variation in, and unequal access to publicly funded breast reduction. A number of priorities for further research have been identified:

- A validated system for how breast hypertrophy should be defined, and which preoperative measurements, symptoms, and outcome variables should be reported in studies 
- Evaluation of which volumes/weights give rise to physical symptoms in relation to body build and other factors

- Analysis of what healthcare needs breast hypertrophy gives rise to

- A validated classification system for prospective registration of complications after breast reduction

- Health economical evaluation of the cost-utility of breast reduction compared with no surgery

- Further studies on women's experiences of breast reduction.

\begin{abstract}
Abbreviations
BDI: Beck's depression inventory; BMI: Body mass index $\left(\mathrm{kg} / \mathrm{m}^{2}\right)$; Cl: Confidence interval; DAS-59: Derriford appearance scale 59; EQ-5D: EuroQol-5 dimension; FBAS: Finnish breast-associated symptoms questionnaire; FPQ: Finnish pain questionnaire; FSFI: Female sexual function index; GRADE: The grading of recommendations assessment, development and evaluation; HADS: Hospital anxiety and depression scale; HAQ-20: Stanford Health Assessment Questionnaire; HTA: Health technology assessment; HRQoL: Health-related quality of life; MD: Mean difference; MID: Minimal important difference; NAC: Nipple areolar complex; NSQIP: The American College of Surgeons National Surgical Quality Improvement Program (ACS NSQIP ${ }^{\circledR}$ ); PICO: $\mathrm{P}=$ patients, I = intervention, $C=$ comparison, $\mathrm{O}=$ outcome; $\mathrm{QALY}$ : Quality adjusted life years; RBDI: Raitsalo's modification of the BDI (Finnish modification); RCT: Randomised controlled trial; SBU: Swedish Agency of Health Technology Assessment and Assessment of Social Services; SF-36: Short Form (36) Health Survey; SF-6D: Short Form Six-Dimension; SQoL-F: Sexual quality of life-female; VAS: Visual analogue scale; WMD: Weighted mean difference.
\end{abstract}

\section{Supplementary Information}

The online version contains supplementary material available at https://doi. org/10.1186/s12893-021-01336-7.

Additional file 1. Search strategies.

Additional file 2. Excluded studies.

Additional file 3. Complications.

Additional file 4. Experience of breast reduction.

\section{Acknowledgements}

Not applicable.

\section{Authors' contributions}

EWJ made substantial contribution to the design of the study and acquisition and analysis of data and drafted the manuscript. ME made substantial contribution to the design of the study and the acquisition and analysis of data and revised the manuscript. HH made substantial contribution to the design of the study and the acquisition and analysis of data and revised the manuscript. CJ made substantial contribution to the design of the study and the acquisition and analysis of data and revised the manuscript. $\downarrow J$ made substantial contribution to the design of the study and the acquisition and analysis of data and revised the manuscript. AL made substantial contribution to the design of the study and the acquisition and analysis of data and revised the manuscript. MP made substantial contribution to the design of the study and the acquisition and analysis of data and revised the manuscript. MS made substantial contribution to the design of the study and the acquisition and analysis of data and revised the manuscript. FW made substantial contribution to the design of the study and the acquisition and analysis of data and revised the manuscript. ME made substantial contribution to the design of the study and the acquisition and analysis of data and revised the manuscript. SB made substantial contribution to the design of the study and the acquisition and analysis of data and revised the manuscript. EH made substantial contribution to the design of the study and the acquisition and analysis of data and revised the manuscript. All authors read and approved the final manuscript.

\section{Funding}

Open access funding provided by University of Gothenburg. The study was funded by grants from the federal government under the ALF agreement (ALFGBG-724171). The source of funding had no role in the design of the study and collection, analysis, and interpretation of data and in writing the manuscript.

\section{Availability of data and materials}

The datasets supporting the conclusions of this article are included with the article and its electronic supplements.

\section{Declarations}

Ethics approval and consent to participate

Not applicable.

\section{Consent for publication}

Not applicable.

\section{Competing interests}

The authors declare that they have no competing interests.

\section{Author details}

'Department of Clinical Sciences, Sahlgrenska Academy, University of Gothenburg, Gröna Stråket 8, SE-413 45 Gothenburg, Sweden. ${ }^{2}$ Department of Plastic and Reconstructive Surgery, Region Västra Götaland, Sahlgrenska University Hospital, Gröna Stråket 8, SE-413 45, Gothenburg, Sweden. ${ }^{3}$ Region Västra Götaland, Research and Development Primary Health Care, Kungsgatan 12, SE-411 19 Gothenburg, Sweden. ${ }^{4}$ Health Technology Assessment Centre, Region Västra Götaland, Sahlgrenska University Hospital, Röda Stråket 8, 413 45 Gothenburg, Sweden. ${ }^{5}$ Department of Health and Rehabilitation, Institute of Neuroscience and Physiology, The Sahlgrenska Academy, University of Gothenburg, Gothenburg, Sweden. ${ }^{6}$ Department of Surgery, Region Västra Götaland, Sahlgrenska University Hospital, Blå Stråket, 41346 Gothenburg, Sweden. ${ }^{7}$ Region Västra Götaland, Sahlgrenska University Hospital, Medical Library, Vita Stråket 12, SE-413 45 Gothenburg, Sweden. ${ }^{8}$ School of Public Health and Community Medicine, Institute of Medicine, University of Gothenburg, Gothenburg, Sweden. ${ }^{9}$ Health Metrics, The Sahlgrenska Academy, University of Gothenburg, Gothenburg, Sweden.

Received: 17 February 2021 Accepted: 28 August 2021

Published online: 11 September 2021

\section{References}

1. Cook SA, Rosser R, Meah S, James MI, Salmon P. Clinical decision guidelines for NHS cosmetic surgery: analysis of current limitations and recommendations for future development. Br J Plast Surg. 2003;56(5):429-36.

2. Hunter JE, Laing JH, Carroll G. Demand management in plastic surgery for low priority procedures: the Welsh experience. J Plast Reconstr Aesthet Surg. 2010;63(11):1778-86.

3. Rahman S, Langridge B, Hachach-Haram N, Hansen E, Bootle A, Bystrzonowski N, Hamilton S, Mosahebi A. Assessing the effects of changes in care commissioning guidelines at a tertiary centre in London on the provision of NHS-funded procedures of limited clinical effectiveness: an 11-year retrospective database analysis. BMJ Open. 2017;7(7): e015324.

4. Henderson J. The plastic surgery postcode lottery in England. Int J Surg. 2009; 7(6):550-8.

5. Wraight WM, Tay SK, Nduka C, Pereira JA. Bilateral breast reduction surgery in England: a postcode lottery. J Plast Reconstr Aesthet Surg. 2007;60(9):1039-44.

6. Russell J, Swinglehurst D, Greenhalgh T. "Cosmetic boob jobs" or evidence-based breast surgery: an interpretive policy analysis of the 
rationing of "Iow value" treatments in the English National Health Service. BMC Health Serv Res. 2014;14:413.

7. Dickie EE, Simcock JW. Reduction mammaplasty and resource allocation-are patients being treated fairly? An examination of the current New Zealand situation, and looking towards the future. N Z Med J. 2013;126(1374):46-55.

8. Klassen A, Fitzpatrick R, Jenkinson C, Goodacre T. Should breast reduction surgery be rationed? A comparison of the health status of patients before and after treatment: postal questionnaire survey. BMJ. 1996;313(7055):454-7.

9. Koltz PF, Frey JD, Langstein HN. Insurance coverage and reduction mammaplasty: a systematic review of current health care policies. Plast Reconstr Surg. 2013;132(4):692e-3e.

10. Schnur PL, Hoehn JG, Ilstrup DM, Cahoy MJ, Chu CP. Reduction mammaplasty: cosmetic or reconstructive procedure? Ann Plast Surg. 1991;27(3):232-7.

11. Kerrigan CL, Collins ED, Striplin D, Kim HM, Wilkins E, Cunningham B, Lowery J. The health burden of breast hypertrophy. Plast Reconstr Surg. 2001;108(6):1591-9.

12. Lewin R, Liden M, Lundberg J, Hansson E, Selvaggi G, Thorarinsson A, Elander A. Prospective evaluation of health after breast reduction surgery using the Breast-Q, Short-Form 36, breast-related symptoms questionnaire, and modified breast evaluation questionnaire. Ann Plast Surg. 2019:83(2):143-51.

13. Crittenden T, Watson DI, Ratcliffe J, Griffin PA, Dean NR, Group AR. Does breast reduction surgery improve health-related quality of life? A prospective cohort study in Australian women. BMJ Open. 2020;10(2): e031804.

14. Mello AA, Domingos NA, Miyazaki MC. Improvement in quality of life and self-esteem after breast reduction surgery. Aesthetic Plast Surg. 2010;34(1):59-64.

15. Dreher R, Blaya C, Tenorio JL, Saltz R, Ely PB, Ferrao YA. Quality of life and aesthetic plastic surgery: a systematic review and meta-analysis. Plast Reconstr Surg Glob Open. 2016;4(9): e862.

16. Sandman L, Hansson E. An ethics analysis of the rationale for publicly funded plastic surgery. BMC Med Ethics. 2020;21(1):94.

17. Abdiu A, Elander A, Gerdin B, Hedenbro J, Ringberg A, Troëng T, Wickman M. Bröstreduktionsplastik—bröstförminskade kirurgi vid stor byst. Rapport från experttgruppen för plastikkirurgi: Sverges Kommuner och Landsting; 2008.

18. Loughry CW, Sheffer DB, Price TE, Einsporn RL, Bartfai RG, Morek WM, Meli NM. Breast volume measurement of 598 women using biostereometric analysis. Ann Plast Surg. 1989;22(5):380-5.

19. Atterhem H, Holmner S, Janson PE. Reduction mammaplasty: symptoms, complications, and late results. A retrospective study on 242 patients. Scand J Plast Reconstr Surg Hand Surg. 1998;32(3):281-6.

20. Sigurdson LJ, Kirkland SA. Breast volume determination in breast hypertrophy: an accurate method using two anthropomorphic measurements. Plast Reconstr Surg. 2006;1 18(2):313-20.

21. Sacchini V, Luini A, Tana S, Lozza L, Galimberti V, Merson M, Agresti $\mathrm{R}$, Veronesi P, Greco M. Quantitative and qualitative cosmetic evaluation after conservative treatment for breast cancer. Eur J Cancer. 1991;27(11):1395-400.

22. Schnur PL. Reduction mammaplasty-the schnur sliding scale revisited. Ann Plast Surg. 1999:42(1):107-8.

23. Hansson E, Eriksson M, Hallberg H, Jepsen C, Jivegård L, Liljegren A, Petzold M, Svensson M, Widmark-Jensen E, Wärnberg F et al. Effectiveness and safety of breast reduction surgery, compared with no surgery, in women with symptomatic breast hypertrophy. Regional activity-based HTA 2021:121. Gothenburg: Västra Götalandsregionen, Sahlgrenska Universitetssjukhuset, HTA-centrum: 2021.

24. Moher D, Shamseer L, Clarke M, Ghersi D, Liberati A, Petticrew M, Shekelle P, Stewart LA, Group P-P. Preferred reporting items for systematic review and meta-analysis protocols (PRISMA-P) 2015 statement. Syst Rev. 2015;4:1.

25. Guyatt GH, Oxman AD, Kunz R, Brozek J, Alonso-Coello P, Rind D, Devereaux PJ, Montori VM, Freyschuss B, Vist G, et al. GRADE guidelines 6. Rating the quality of evidence-imprecision. J Clin Epidemiol. 2011;64(12):1283-93.

26. Guyatt GH, Oxman AD, Kunz R, Woodcock J, Brozek J, Helfand M, Alonso-Coello P, Falck-Ytter Y, Jaeschke R, Vist G, et al. GRADE guidelines:
8. Rating the quality of evidence-indirectness. J Clin Epidemiol. 2011;64(12):1303-10.

27. Guyatt GH, Oxman AD, Kunz R, Woodcock J, Brozek J, Helfand M, Alonso-Coello P, Glasziou P, Jaeschke R, Akl EA, et al. GRADE guidelines: 7. Rating the quality of evidence-inconsistency. J Clin Epidemiol. 2011;64(12):1294-302.

28. Guyatt GH, Oxman AD, Montori V, Vist G, Kunz R, Brozek J, AlonsoCoello P, Djulbegovic B, Atkins D, Falck-Ytter Y, et al. GRADE guidelines: 5. Rating the quality of evidence-publication bias. J Clin Epidemiol. 2011;64(12):1277-82.

29. Assessment of methods in health care and social services - a handbook The Swedish Agency for Health Technology Assessment and Assessment of Social Services 2018. Stockholm, Sweden.

30. Guyatt GH, Oxman AD, Vist GE, Kunz R, Falck-Ytter Y, Alonso-Coello P, Schunemann HJ, Group GW. GRADE: an emerging consensus on rating quality of evidence and strength of recommendations. BMJ. 2008;336(7650):924-6.

31. Imuagwu OC, Walker LG, Stanley PW, Hart NB, Platt AJ, Drew PJ. Randomized clinical trial examining psychosocial and quality of life benefits of bilateral breast reduction surgery. Br J Surg. 2006;93(3):291-4.

32. Fairchild B, Wei S, Bartz-Kurycki M, Rose JF, Greives MR. The Influence of obesity on outcomes after pediatric reduction mammaplasty: a retrospective analysis of the pediatric national surgical quality improvement program-pediatric database. Ann Plast Surg. 2020;85(6):608-11.

33. Nelson JA, Fischer JP, Chung CU, West A, Tuggle CT, Serletti JM, Kovach SJ. Obesity and early complications following reduction mammaplasty: an analysis of 4545 patients from the 2005-2011 NSQIP datasets. J Plast Surg Hand Surg. 2014;48(5):334-9.

34. Saariniemi KM, Sintonen $\mathrm{H}$, Kuokkanen $\mathrm{HO}$. The improvement in quality of life after breast reduction is comparable to that after major joint replacement. Scand J Plast Reconstr Surg Hand Surg. 2008;42(4):194-8.

35. Walters SJ, Brazier JE. Comparison of the minimally important difference for two health state utility measures: EQ-5D and SF-6D. Qual Life Res. 2005;14(6):1523-32

36. Sabino Neto M, Dematte MF, Freire M, Garcia EB, Quaresma M, Ferreira LM. Self-esteem and functional capacity outcomes following reduction mammaplasty. Aesthet Surg J. 2008;28(4):417-20.

37. Freire M, Neto MS, Garcia EB, Quaresma MR, Ferreira LM. Functional capacity and postural pain outcomes after reduction mammaplasty. Plast Reconstr Surg. 2007;119(4):1149-56.

38. Shakespeare V, Postle K. A qualitative study of patients' views on the effects of breast-reduction surgery: a 2-year follow-up survey. Br J Plast Surg. 1999;52(3):198-204.

39. Imuagwu OC, Stanley PW, Platt AJ, Drew PJ, Walker LG. Effects of bilateral breast reduction on anxiety and depression: results of a prospective randomised trial. Scand J Plast Reconstr Surg Hand Surg. 2006;40(1):19-23.

40. Araujo CD, Veiga DF, Hochman BS, Abla LE, Oliveira AC, Novo NF, VeigaFilho J, Ferreira LM. Cost-utility of reduction mammaplasty assessed for the Brazilian public health system. Aesthet Surg J. 2014;34(8):1198-204.

41. Beraldo FN, Veiga DF, Veiga-Filho J, Garcia ES, Vilas-Boas GS, Juliano Y, Sabino-Neto M, Ferreira LM. Sexual function and depression outcomes among breast hypertrophy patients undergoing reduction mammaplasty: a randomized controlled trial. Ann Plast Surg. 2016;76(4):379-82.

42. Andrade AC, Veiga DF, Aguiar IC, Juliano $Y$, Sabino-Neto M, Ferreira LM. Outcomes analysis of breast reduction in Brazilian women using the BREAST-Q(R) questionnaire: a cross-sectional controlled study. Clinics (Sao Paulo). 2018;73: e313.

43. Hermans BJ, Boeckx WD, De Lorenzi F, van der Hulst RR. Quality of life after breast reduction. Ann Plast Surg. 2005;55(3):227-31.

44. Spector JA, Singh SP, Karp NS. Outcomes after breast reduction: does size really matter? Ann Plast Surg. 2008;60(5):505-9.

45. Hansson E, Manjer J, Ringberg A. Reliability of plastic cups to measure breast volume. J Plast Surg Hand Surg. 2014;48(4):254-8.

46. Choppin SB, Wheat JS, Gee M, Goyal A. The accuracy of breast volume measurement methods: a systematic review. Breast. 2016;28:121-9.

47. Ringberg A, Bageman E, Rose C, Ingvar C, Jernstrom H. Of cup and bra size: reply to a prospective study of breast size and premenopausal breast cancer incidence. Int J Cancer. 2006;119(9):2242-3; author reply 2244.

48. Winter R, Haug I, Lebo P, Grohmann M, Reischies FMJ, Cambiaso-Daniel J, Tuca A, Rienmuller T, Friedl H, Spendel S, et al. Standardizing the 
complication rate after breast reduction using the Clavien-Dindo classification. Surgery. 2017;161(5):1430-5.

49. Simpson AM, Donato DP, Kwok AC, Agarwal JP. Predictors of complications following breast reduction surgery: A National Surgical Quality Improvement Program study of 16,812 cases. J Plast Reconstr Aesthet Surg. 2019;72(1):43-51.

50. Bond J, Duncan J, Sattar A, Boanas A, Mason T, O'Kane S, Ferguson M. Maturation of the human scar: an observational study. Plast Reconstr Surg. 2008;121(5):1650-8.

51. Beard D, Cooper C, Rombach I, Rees J, Wartolowska K, Cummings N, Carr A. Accounting for the placebo effect of surgery in surgical trials? Trials. 2013. https://doi.org/10.1186/1745-6215-14-S1-P11.

52. Abdelgadir J, Ong EW, Abdalla SM, Hunting JC, Diab MM, Haglund MM, Goodwin CR, Nelli A, Gulur P. Demographic factors associated with patient-reported outcome measures in pain management. Pain Phys. 2020;23(1):17-24.

53. Pluvy I, Panouilleres M, Garrido I, Pauchot J, Saboye J, Chavoin JP, Tropet Y, Grolleau JL, Chaput B. Smoking and plastic surgery, part II. Clinical implications: a systematic review with meta-analysis. Ann Chir Plast Esthet. 2015:60(1):e15-49.

54. Klassen A, Jenkinson C, Fitzpatrick R, Goodacre T. Patients' health related quality of life before and after aesthetic surgery. Br J Plast Surg. 1996;49(7):433-8.

55. Barone M, Cogliandro A, Salzillo R, Tambone V, Persichetti P. The role of appearance: definition of appearance-pain (app-pain) and systematic review of patient-reported outcome measures used in literature. Aesthetic Plast Surg. 2018;42(5):1399-409.

56. Cook SA, Rosser R, Salmon P. Is cosmetic surgery an effective psychotherapeutic intervention? A systematic review of the evidence. J Plast Reconstr Aesthet Surg. 2006;59(11):1133-51.

57. Saariniemi KM, Joukamaa M, Raitasalo R, Kuokkanen HO. Breast reduction alleviates depression and anxiety and restores self-esteem: a prospective randomised clinical trial. Scand J Plast Reconstr Surg Hand Surg. 2009;43(6):320-4.

58. Saariniemi KM, Kuokkanen $\mathrm{HO}$, Rasanen $\mathrm{P}$, Sintonen $\mathrm{H}$, Tukiainen EJ. The cost utility of reduction mammaplasty at medium-term follow-up: a prospective study. J Plast Reconstr Aesthet Surg. 2012;65(1):17-21.
59. Taylor AJ, Tate D, Brandberg Y, Blomqvist L. Cost-effectiveness of reduction mammaplasty. Int J Technol Assess Health Care. 2004;20(3):269-73.

60. Thoma A, Kaur MN, Tsoi B, Ziolkowski N, Duku E, Goldsmith CH. Costeffectiveness analysis parallel to a randomized controlled trial comparing vertical scar reduction and inverted T-shaped reduction mammaplasty. Plast Reconstr Surg. 2014;134(6):1093-107.

61. Tykka E, Rasanen P, Tukiainen E, Asko-Seljavaara S, Heikkila A, Sintonen H, Roine RP. Cost-utility of breast reduction surgery - a prospective study. J Plast Reconstr Aesthet Surg. 2010;63(1):87-92.

62. Janik PE, Charytonowicz D, Miszczyk J, Charytonowicz M. Female sexual function and sexual well-being before and after breast reduction: a pilot cross-sectional study and review of literature. Ann Plast Surg. 2019;82(6):609-13.

63. Button KS, Kounali D, Thomas L, Wiles NJ, Peters TJ, Welton NJ, Ades AE, Lewis G. Minimal clinically important difference on the Beck Depression Inventory-II according to the patient's perspective. Psychol Med. 2015:45(15):3269-79.

64. Lemay KR, Tulloch HE, Pipe AL, Reed JL. Establishing the minimal clinically important difference for the hospital anxiety and depression scale in patients with cardiovascular disease. J Cardiopulm Rehabil Prev. 2019;39(6):E6-11.

65. Krychman M, Rowan CG, Allan BB, Durbin S, Yacoubian A, Wilkerson D. Effect of single-session, cryogen-cooled monopolar radiofrequency therapy on sexual function in women with vaginal laxity: the VIVEVE I Trial. J Womens Health (Larchmt). 2018;27(3):297-304.

66. Kelly AM. Does the clinically significant difference in visual analog scale pain scores vary with gender, age, or cause of pain? Acad Emerg Med. 1998;5(11):1086-90.

\section{Publisher's Note}

Springer Nature remains neutral with regard to jurisdictional claims in published maps and institutional affiliations.
Ready to submit your research? Choose BMC and benefit from:

- fast, convenient online submission

- thorough peer review by experienced researchers in your field

- rapid publication on acceptance

- support for research data, including large and complex data types

- gold Open Access which fosters wider collaboration and increased citations

- maximum visibility for your research: over 100M website views per year

At BMC, research is always in progress.

Learn more biomedcentral.com/submissions 